\title{
Rare Earth Metals: Resourcefulness and Recovery
}

\author{
SHIJIE WANG ${ }^{1,2}$ \\ 1.-Rio Tinto Kennecott Utah Copper, South Jordan, UT, USA. 2.-e-mail: wangs@kennecott.com
}

\begin{abstract}
When we appreciate the digital revolution carried over from the twentieth century with mobile communication and the Internet, and when we enjoy our high-tech lifestyle filled with iDevices, hybrid cars, wind turbines, and solar cells in this new century, we should also appreciate that all of these advanced products depend on rare earth metals to function. Although there are only 136,000 tons of annual worldwide demand, (Cho, Rare Earth Metals, Will We Have Enough? $)^{1}$ rare earth metals are becoming such hot commodities on international markets, due to not only to their increasing uses, including in most critical military hardware, but also to Chinese growth, which accounts for $95 \%$ of global rare earth metal production. Hence, the 2013 technical calendar topic, planned by the TMS/Hydrometallurgy and Electrometallurgy Committee, is particularly relevant, with four articles (including this commentary) contributed to the JOM October Issue discussing rare earth metals' resourcefulness and recovery.
\end{abstract}

\section{RARE EARTH METALS}

Rare earth metals are a group of 17 metals occurring in Group 3 of the Mendeleev periodic table, as illustrated in Fig. 1 with their relationship to the other members.

The group consists of the following elements: scandium (Sc), yttrium (Y), and lanthanum (La), all of which appear in column III B of the periodic table, and the elements with atomic numbers ranging from 58 to 71: cerium (Ce), praseodymium (Pr), neodymium (Nd), promethium (Pm), samarium $(\mathrm{Sm})$, europium $(\mathrm{Eu})$, gadolinium $(\mathrm{Gd})$, terbium (Tb), dysprosium (Dy), holmium (Ho), erbium (Er), thulium $(\mathrm{Tm})$, ytterbium $(\mathrm{Yb})$, and lutetium $(\mathrm{Lu})$.

They are usually placed at the bottom of the periodic table and called the lanthanide ( $\mathrm{Ln})$ rare earths or, more generally, the lanthanides Ln. The Ln series of rare earths can be divided into two groups: the Cerite earths, consisting of the oxides of $\mathrm{Ce}, \mathrm{La}, \mathrm{Pr}, \mathrm{Nd}$, and $\mathrm{Sm}$, and the Gadolinite earths consisting of the oxides of Gd, Sc, Y, Tb, Dy, Ho, Er, Tm, Yb, and Lu.

The term "rare earths" was originally used to describe the oxides of the metals belonging to the Ln

Shijie Wang is the guest editor for the Hydrometallurgy and Electrometallurgy Committee of the TMS Extraction \& Processing Division, and coordinator of the topic Rare Earth Metals: Resourcefulness and Recovery in this issue. series, but it is now used to designate a second series of oxides known as the actinide series; the atomic numbers ranging, as currently known, from 90 to 100 , are placed at the bottom of the periodic table.

Like a cameo exhibition, ultra-purity rare earth metals and ultra-purity rare earth oxides, 16 samples of each, are shown in Fig. 2.

An interesting finding is that the rare earth minerals contain almost no Sc. That is because Sc 21 is generally produced as a by-product of uranium mining.

Also, Pm does not have a stable isotope, so it does not appear in the Earth's crust. Kilogram amounts of $\mathrm{Pm}_{2} \mathrm{O}_{3}$ have been separated from reactor wastes at Hanford. ${ }^{2}$ It turns out that there are 14 elements in the Ln series, but Pm 61 is missing.

\section{RESOURCEFULNESS}

Rare earths do not occur in nature in the elemental (metallic) state and, except for Sc, they do not occur in minerals as individual rare earth metal. The rare earths are widely distributed in low concentrations throughout the earth's crust, as shown in Table I. ${ }^{3}$

The minerals containing the rare earths occur in only a few localities. Each mineral contains several of the rare earths, and the proportions are not constant in all specimens. Usually the minerals are very complex and a chemical formula is not known in all 
cases. Rare earth elements commonly substitute each other in natural minerals; consequently, when one element is present, many others are also present;

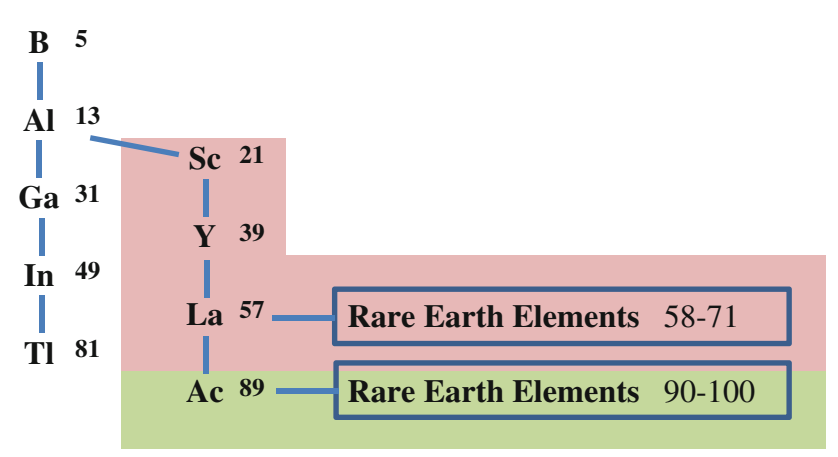

Fig. 1. Illustrated Group 3 of the Mendeleev periodic table. their chemical formula sometime can be very complex. The following formulas are commonly accepted as indicating the major constituents:

Monazite $(\mathrm{R}) \mathrm{PO}_{4}$ where $\mathrm{R}=\mathrm{Ce}, \mathrm{La}, \mathrm{Nd}, \mathrm{Sm}, \mathrm{Gd}$, etc.

Bastnasite $(\mathrm{R}) \mathrm{CO}_{3} \mathrm{~F}$ where $\mathrm{R}=\mathrm{Ce}, \mathrm{La} . \mathrm{Y}$, other $\mathrm{RE}$, etc.

Fergusonite $(\mathrm{R}) \mathrm{NbO}_{4}$ where $\mathrm{R}=\mathrm{Ce}, \mathrm{La}, \mathrm{Nd}, \mathrm{Y}$, etc.

Xenotime $\mathrm{YPO}_{4}, \mathrm{YbPO}_{4}$

Cerite- $\mathrm{La}(\mathrm{La}, \mathrm{Ce}, \mathrm{Ca})_{9}(\mathrm{Fe}, \mathrm{Ca}, \mathrm{Mg})\left(\mathrm{SiO}_{4}\right)_{3}\left[\mathrm{SiO}_{3} \cdot \mathrm{OH}\right]_{4}$ $(\mathrm{OH})_{3}$

More than 95\% of the rare earth oxides occur in three minerals: monazite and bastnaesite for the light rare earths, and xenotime for $\mathrm{Y}$ and the heavy rare earths. The rare earth metals resourcefulness can be summarized as:
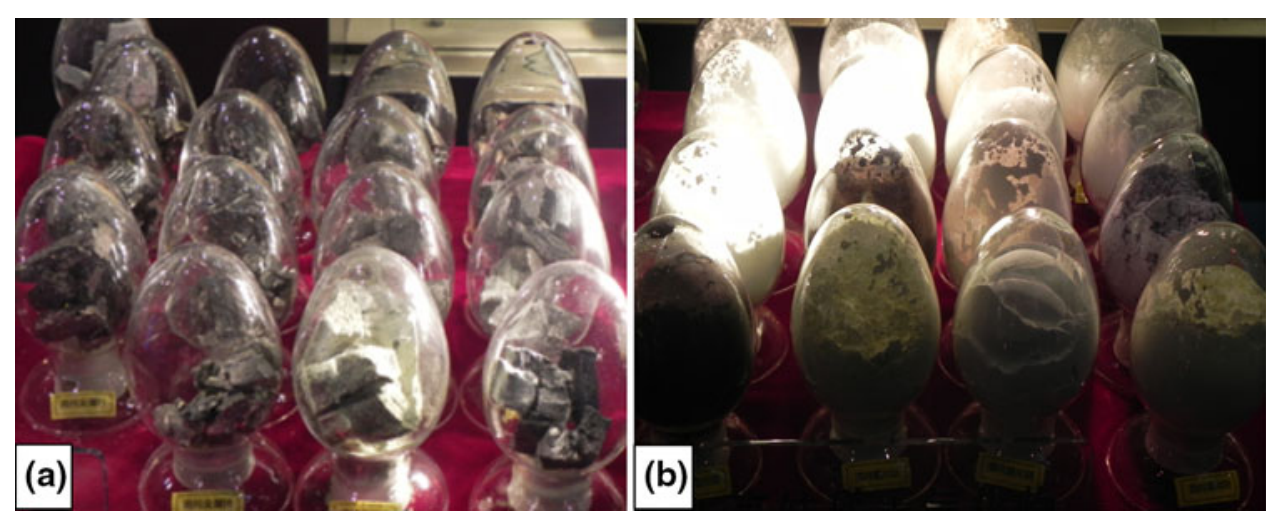

Fig. 2. (a) Ultra-purity rare earth metals and (b) ultra-purity RE oxides (Source GRINM exhibition).

Table I. Typical abundance of rare earths in some rocks and minerals

\begin{tabular}{|c|c|c|c|c|c|c|c|}
\hline Element & Rank* & $\begin{array}{c}\text { Kilauea Basalt } \\
\text { (ppm) }\end{array}$ & $\begin{array}{c}\text { Precambrian } \\
\text { Granites (ppm) }\end{array}$ & $\begin{array}{l}\text { North American } \\
\text { Shales (ppm) }\end{array}$ & $\begin{array}{c}\text { S. Carolina } \\
\text { Monazite } \\
\text { wt } \%, \mathrm{R}_{2} \mathrm{O}_{3}\end{array}$ & $\begin{array}{c}\text { California } \\
\text { Bastnaesite } \\
{ }_{\mathrm{wt}} \%, \mathrm{R}_{2} \mathrm{O}_{3}\end{array}$ & $\begin{array}{l}\text { Malaysia } \\
\text { Xenotime } \\
\mathrm{wt} \%, \mathrm{R}_{2} \mathrm{O}_{3}\end{array}$ \\
\hline $\mathrm{Y}$ & 31 & & 31.00 & 35.00 & 3.00 & 0.10 & 60.80 \\
\hline $\mathrm{La}$ & 35 & 10.50 & 49.00 & 39.00 & 19.50 & 32.00 & 0.50 \\
\hline $\mathrm{Ce}$ & 29 & 35.00 & 97.00 & 76.00 & 44.00 & 49.00 & 5.00 \\
\hline $\operatorname{Pr}$ & 45 & 3.90 & 11.00 & 10.30 & 5.80 & 4.40 & 0.70 \\
\hline $\mathrm{Nd}$ & 32 & 17.80 & 42.00 & 37.00 & 19.20 & 13.50 & 2.20 \\
\hline \multicolumn{8}{|l|}{$\mathrm{Pm}$} \\
\hline $\mathrm{Sm}$ & 42 & 4.20 & 7.20 & 7.00 & 4.00 & 0.50 & 1.90 \\
\hline $\mathrm{Eu}$ & 57 & 1.31 & 1.25 & 2.00 & 0.17 & 0.10 & 0.20 \\
\hline Gd & 43 & 4.70 & 5.80 & 6.10 & 2.00 & 0.30 & 4.00 \\
\hline $\mathrm{Tb}$ & 59 & 0.66 & 0.94 & 1.30 & 0.20 & & 1.00 \\
\hline Dy & 50 & 3.00 & & & 1.30 & & 8.70 \\
\hline Ho & 56 & 0.64 & 1.22 & 1.40 & 0.10 & Total & 2.10 \\
\hline Er & 54 & 1.69 & 3.20 & 4.00 & 0.50 & 0.10 & 5.40 \\
\hline $\mathrm{Tm}$ & 65 & 0.21 & 0.53 & 0.58 & & & 0.90 \\
\hline $\mathrm{Yb}$ & 53 & 1.11 & 3.50 & 3.40 & 0.20 & & 6.20 \\
\hline $\mathrm{Lu}$ & 60 & 0.20 & 0.52 & 0.60 & & & 0.40 \\
\hline
\end{tabular}

*Ranks of 1-90 are relative measures of the abundance of each element in the Earth's crust. 
- Primary resources-Bastnasite deposits in China (Baotou Bayan Obo) and the United States (Mountain Pass in southeastern California) constitute the largest percentage of the world's rare earth economic resources, while monazite deposits in Australia, Brazil, China, India, Malaysia, South Africa, Sri Lanka, Thailand, and the United States constitute the second largest segment.

- Other resources of rare earth metals are apatite (group of phosphate minerals, $\mathrm{Ca}_{5}\left(\mathrm{PO}_{4}\right)_{3}$ $(\mathrm{F}, \mathrm{Cl}, \mathrm{OH})$, cheralite [monazite group, $(\mathrm{Ca}, \mathrm{Ce})$ $\left.(\mathrm{Th}, \mathrm{Ce})\left(\mathrm{PO}_{4}\right)_{2}\right]$, eudialyte $\left[\mathrm{Na}_{15} \mathrm{Ca}_{6}(\mathrm{Fe}, \mathrm{Mn})_{3} \mathrm{Zr}_{3}\right.$ $\mathrm{SiO}_{3}$ ], loparite $\left(\mathrm{CeTiO}_{3}\right)$, phosphorites (or phosphate rock, rare earth-bearing (ion adsorption) clays, secondary monazite, spent uranium solutions, and xenotime.

- Undiscovered resources are thought to be very large relative to expected demand. A very large resource enriched in heavy rare earth elements is inferred for phosphorites of the Florida Phosphate District. Also, a large deposit of rare earth miner-

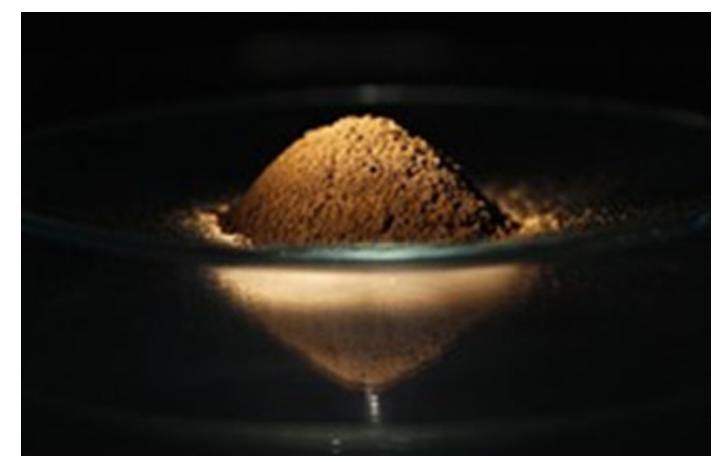

Fig. 3. The seabed mud sample containing rich rare earth metals. ${ }^{4}$ als on the ocean floor existing in the mud (Fig. 3) across a $1000-\mathrm{m}^{2}$ seabed near Japan was explored and contains an estimated 6.8 million metric tons of rare earth minerals, including Dy. ${ }^{4}$

Occurrences The general formula for $\mathrm{RE}$ oxides is $\mathrm{R}_{2} \mathrm{O}_{3}$, or $\mathrm{Ln}_{2} \mathrm{O}_{3}$ (REO), but in the case of the first member of the group, Ce, the most stable oxide is $\mathrm{CeO}_{2}$. Followed by their occurrences, the typical content of rare earth of main rare earth mines in the world is listed in Table II.

\section{RECOVERY}

Bastnaesite and monazite are minerals used commercially to supply most of the rare earth chemicals. Those deposits are thought to be an artifact of ancient sea beds that were forced up in the process of mountain building. Such deposits are dredged, pulverized if necessary, and further enriched by flotation methods. Sometimes they are also subjected to cross-belt magnetic separation because they are weakly magnetic.

Beneficiated monazite or bastnaesite can be broken open by acid or caustic and the lanthanons made water-soluble. It is then possible to proceed using several methods to produce mixed rare earth oxides, fluorides, nitrates, hydroxides, or carbonates within a simple, straightforward chemical operation.

Due to increasingly stringent environmental regulations and challenges, many rare earth metal hydrometallurgical processes have been developed for comprehensive utilization of resources, innovative separation and purification of rare earth metals, and environmentally reducing or eliminating the air pollution, waste solution, and hazardous landfills.

As shown in Fig. 4, a rotary kiln roasting-solvent extraction technology was developed by the Gen-

Table II. Typical rare earth contents in major rare earth mines in the world ${ }^{5}$

\begin{tabular}{|c|c|c|c|c|c|c|c|c|}
\hline \multirow[b]{2}{*}{ Constituent } & \multirow{2}{*}{$\begin{array}{l}\text { China } \\
\text { Baotou RE ore }\end{array}$} & \multicolumn{3}{|c|}{$\begin{array}{c}\text { China Jiangxi ion } \\
\text { adsorption type RE ores }\end{array}$} & \multirow{2}{*}{$\begin{array}{c}\text { U.S. } \\
\text { Bastanesite }\end{array}$} & \multirow{2}{*}{$\begin{array}{c}\text { Former } \\
\text { USSR } \\
\text { Perovskite }\end{array}$} & \multirow{2}{*}{$\begin{array}{l}\text { Australia } \\
\text { Monazite }\end{array}$} & \multirow{2}{*}{$\begin{array}{l}\text { Malaysia } \\
\text { Xenotime }\end{array}$} \\
\hline & & Xunwu & Xinfeng & Longnan & & & & \\
\hline $\mathrm{La}_{2} \mathrm{O}_{3}$ & 25.00 & 38.00 & 27.56 & 2.18 & 32.00 & 25.00 & 23.90 & 1.26 \\
\hline $\mathrm{CeO}_{2}$ & 50.07 & 3.50 & 3.23 & $<1.09$ & 49.00 & 50.00 & 46.40 & 3.17 \\
\hline $\operatorname{Pr}_{6} \mathrm{O}_{11}$ & 5.10 & 7.41 & 5.62 & 1.08 & 4.40 & 5.00 & 5.05 & 0.50 \\
\hline $\mathrm{Nd}_{2} \mathrm{O}_{3}$ & 16.60 & 30.18 & 17.55 & 3.47 & 13.50 & 15.00 & 17.38 & 1.61 \\
\hline $\mathrm{Sm}_{2} \mathrm{O}_{3}$ & 1.20 & 5.32 & 4.54 & 2.37 & 0.50 & 0.70 & 2.52 & 1.16 \\
\hline $\mathrm{Eu}_{2} \mathrm{O}_{3}$ & 0.18 & 0.51 & 0.93 & $<0.37$ & 0.10 & 0.09 & 0.05 & 0.01 \\
\hline $\mathrm{Gd}_{2} \mathrm{O}_{3}$ & 0.70 & 4.21 & 5.96 & 5.69 & 0.30 & 0.60 & 1.49 & 3.52 \\
\hline $\mathrm{Th}_{2} \mathrm{O}_{3}$ & $<0.1$ & 0.46 & 0.68 & 1.13 & 0.01 & & 0.04 & 0.92 \\
\hline $\mathrm{Dy}_{2} \mathrm{O}_{3}$ & $<0.1$ & 1.77 & 3.71 & 7.48 & 0.03 & 0.60 & 0.69 & 8.44 \\
\hline $\mathrm{Ho}_{2} \mathrm{O}_{3}$ & $<0.1$ & 0.27 & 0.74 & 1.60 & 0.01 & 0.70 & 0.05 & 2.01 \\
\hline $\mathrm{Er}_{2} \mathrm{O}_{3}$ & $<0.1$ & 0.88 & 2.48 & 4.26 & 0.01 & 0.80 & 0.21 & 6.52 \\
\hline $\mathrm{Tm}_{2} \mathrm{O}_{3}$ & $<0.1$ & 0.13 & 0.27 & 0.60 & 0.02 & 0.10 & 0.01 & 1.14 \\
\hline $\mathrm{Yb}_{2} \mathrm{O}_{3}$ & $<0.1$ & 0.62 & 1.13 & 3.34 & 0.01 & 0.20 & 0.12 & 6.87 \\
\hline $\mathrm{Lu}_{2} \mathrm{O}_{3}$ & $<0.1$ & 0.13 & 0.21 & 0.47 & 0.01 & 0.15 & 0.04 & 1.00 \\
\hline $\mathrm{Y}_{2} \mathrm{O}_{3}$ & 0.43 & 10.07 & 24.26 & 64.97 & 0.10 & 1.30 & 2.41 & 61.87 \\
\hline
\end{tabular}




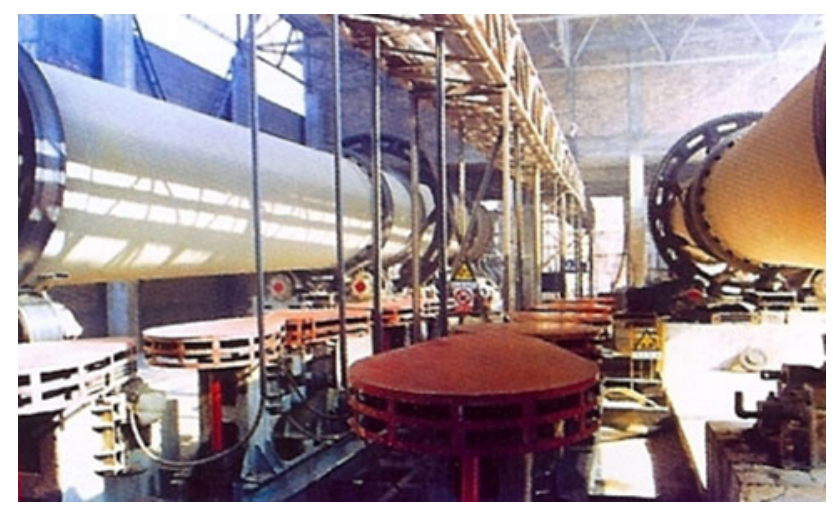

Fig. 4. Rotary kiln roasting-solvent extraction technology in Baotou, China (GRINM report).

eral Research Institute for Non-Ferrous Metals (GRINM) for treating Baotou mixed-type rare earth concentrate (bastnaesite:monazite $=3: 1$ ) in China.

\section{IN THIS ISSUE}

In this issue of JOM, there are three submitted articles that have been compiled for providing a snapshot of technological developments and updates for rare earth metals' resourcefulness and recoveries.

In "A Primer on Hydrometallurgical Rare Earth Separations" by B. Kronholm, C.G. Anderson, and P.R. Taylor, the history of hydrometallurgical total rare earth oxide separations and technologies is delineated, and recently published research into the key aspects of rare earths separation, viz., oxidation/reduction, fractional crystallization, ion exchange, and solvent extraction, is detail described.

In "Material and Energy Requirement for Rare Earth Production," Laura Talens Peiro and Gara Villalba Mendez indicate that the material and energy requirement varies greatly depending on the type of mineral ore, production facility, and beneficiation process selected. The study indicates that the greatest power consumption occurs during mining (25-50\%) and beneficiation (10-30\%) of rare earth minerals.

In "Refining and Mutual Separation of Rare Earths Using Biomass Wastes," Katsutoshi Inoue and Shafiq Alam report two different types of adsorption gels, polyphenol compound and basic polysaccharide being prepared and employed for removing radioactive uranium and thorium from lutetium as well as mutual separation among light rare earths. Results from the lab scale tests are promising for use in inexpensive gels and products from biomass wastes in the recovery of highly purified rare earths.

\section{REFERENCES}

1. R. Cho, Rare Earth Metals, Will We Have Enough? (New York: Columbia University, The Earth Institute, 2012).

2. E.J. Wheelwright, Promethium Technology (Hinsdale, IL: American Nuclear Society, 1973).

3. K.A. Gschneidner and L. Eyring, eds., Handbook on the Physics and Chemistry of the Rare Earths of Metals, Vol. I (Amsterdam: North Holland, 1979).

4. Y. Koh, Wall Street J. Jpn. (July 22, 2013).

5. J. Qian and G. Li, Chin. J. Rare Met. 27, 814-818 (2003). 